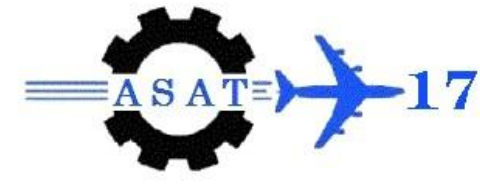

\title{
Performance, Emission and Combustion Characteristics Analysis of Jatropha Biodiesel Blends Compared to Diesel Fuel
}

\author{
S.M. Abdel Razek ${ }^{*}$, M. S. Gad ${ }^{\dagger}$
}

\begin{abstract}
Increased environmental concern and depletion of fossil petroleum fuel are the driving forces to promote biodiesel as a green alternative fuel for diesel engine. Biodiesel has immense potential to reduce pollutant emissions and not require significant modification of existing engine hardware. In this study, experimental investigations have been done on a four stroke, single cylinder diesel engine to examine performance, emissions and combustion characteristics of biodiesel blends (B5, B10, B15 and B20) of Jatropha methyl ester in comparison to diesel fuel. These experiments were conducted at different engine loads with the injection timing prescribed by the engine manufacturer. Results indicated that properties of methyl esters of Jatropha (JME) derived through transesterification process and its blends were within acceptable limits of ASME standards. Brake thermal efficiency of Jatropha biodiesel blends with diesel were lower than fossil diesel however, brake specific fuel consumption was found to be higher. Moreover, it can reduce smoke opacity, unburned hydrocarbons, carbon dioxide and carbon monoxide emissions but nitrogen oxides emissions have slightly increased. Biodiesel produces from non-edible oils like Jatropha could be a good substitute to diesel fuel in diesel engine.
\end{abstract}

Keywords: Jatropha Methyl Ester, diesel engine, performance, emission, combustion characteristics.

\section{Nomenclature}

ATDC After Top Dead Center.

$\mathrm{A} / \mathrm{F} \quad$ Air/fuel mass ratio, $\mathrm{kg}$ of air/ $\mathrm{kg}$ of fuel.

BTDC Before Top Dead center.

BSFC Brake specific fuel consumption, $\mathrm{kg} / \mathrm{kW} \mathrm{h}$

BP Brake power, $\mathrm{kW}$.

C.A. Crank angle.

CO Carbon monoxide, $\%$.

D100 Neat diesel fuel.

JMEB5 Fuel blend containing 5\% Jatropha methyl ester biodiesel and 95\% neat diesel.

JMEB10 Fuel blend containing 10\% Jatropha methyl ester biodiesel and 90\% neat diesel.

JMEB15 Fuel blend containing 15\% Jatropha methyl ester biodiesel and 85\% neat diesel.

JMEB20 Fuel blend containing 20\% Jatropha methyl ester biodiesel and 80\% neat diesel.

Rpm Revolution per minute.

$\mathrm{NO}_{\mathrm{X}} \quad$ Nitric oxide, $\mathrm{ppm}$.

Mechanical Engineering Department, Faculty of Engineering, Miser University for Science and Technology, 6th October City, Egypt.

$\dagger \quad$ Mechanical Engineering Department, National Research centre, Egypt; mgad27@yahoo.com . 


$\begin{array}{ll}\mathrm{P}_{\text {cyl }} & \text { In-cylinder pressure, } \mathrm{kPa} . \\ \mathrm{P}_{\max } & \text { Maximum in cylinder pressure, bar. } \\ \mathrm{T}_{\text {exh }} & \text { Exhaust gas temperature, } \mathrm{K} . \\ \mathrm{UHC} & \text { Unburned hydrocarbon carbon, ppm. } \\ \mathrm{\eta}_{\mathrm{B}} & \text { Brake thermal efficiency, } \% .\end{array}$

\section{Introduction}

Biodiesel either in crude form or as a mixture with diesel fuel is widely investigated to solve problems of fossil fuels depletion and environmental degradation. Biodiesel as an alternative fuel of diesel is described as fatty acid methyl or ethyl esters from vegetable oils or animal fats by transesterification process. Use of biodiesel has grown dramatically during the last few years. Feedstock costs account for a large portion of direct biodiesel production costs, including capital cost and return. Balat M. [1] and Lu et al. [2] produced the Jatropha biodiesel yield higher than $98 \%$ by transesterification using $1.3 \% \mathrm{KOH}$ by weight as catalyst and molar ratio of methanol to oil $6: 1$ at $64{ }^{\circ} \mathrm{C}$. Kumara et al. [3] investigated that purity and conversion of biodiesel was $99.04 \%$ using continuous coil flow reactor at $70{ }^{\circ} \mathrm{C}$ with potassium hydroxide as a catalyst and oil to methanol molar ratio 1:5. The main drawback of vegetable oil fuel is their higher viscosity and lower volatility, which causes poor combustion in diesel engines including formation of deposits and injector cocking due to poorer atomization upon injection into the combustion chamber. It can be used as liquid engine fuel in various ways such as straight vegetable oil, oil blends, pyrolysis, micro-emulsification andtransesterification in diesel engine [4]. Transesterification of the oil reduces the viscosity of the oil to a range of $4-5 \mathrm{~mm}^{2} / \mathrm{s}$ closer to that of diesel fuel and hence improves combustion [5].

Performance, emission and combustion characteristics of a diesel engine, run on blends of Jatropha methyl/ethyl ester with diesel fuel were investigated. Biodiesel blends improve engine performance, and reduce harmful exhaust emissions. Engine output power and brake thermal efficiency were near to diesel fuel. Biodiesel and diesel fuel blends can reduce smoke opacity, unburned hydrocarbons, carbon dioxide and carbon monoxide emissions but nitrogen oxide emissions have slightly increased [6-9]. Venkata Ramesh Mamilla et al. [10] conducted an experimental investigation to evaluate performance and emission characteristics of a single cylinder, air cooled, four stroke diesel engine fueled with Jatropha methyl ester (JME), and its blends $(20,40,60,80$ and 100\%) with diesel fuel. Lower volume percentages of biodiesel (20\% JME) act as the best alternative fuel among all tested fuel at full load condition.

Syarifah Yunusa et al, [11] study exhaust emissions of Jatropha-Palm blended biodiesels as fuel for four stroke single cylinder diesel engine. Higher $\mathrm{CO}, \mathrm{CO}_{2}$ and $\mathrm{NO}_{\mathrm{x}}$ emissions produced from biodiesel blended as compared to diesel Fuel. Jindal et al. [12] observed that with increasing compression ratio and injection pressure, $\mathrm{HC}, \mathrm{NO}_{\mathrm{x}}$, smoke opacity emissions and exhaust gas temperature are lower for Jatropha oil compared with diesel fuel. Huang et al. [13] conducted an experimental study to evaluate performance and emission characteristics of a diesel engine using Jatropha biodiesel blends. Engine performance and thermal efficiency of diesel engine run Jatropha biodiesel were comparable to pure diesel fuel. Fuel consumptions of diesel engine are slightly higher when fuelled Jatropha biodiesel. The effect of reducing Jatropha oil's viscosity by increasing the fuel temperature by using waste heat of the exhaust gases and various blends of Jatropha oil with diesel oil on exhaust emissions and performance of diesel engine was done by Agarwal D., Agarwal A.K. [14]. Brake specific fuel consumption and exhaust gas temperatures for unheated Jatropha oil found to be higher compared to diesel fuel, and preheated Jatropha oil. Thermal efficiency was lower for unheated Jatropha oil compared to preheated Jatropha oil and diesel fuel. $\mathrm{CO}_{2}, \mathrm{CO}, \mathrm{HC}$, and smoke opacity emissions were higher for Jatropha oil compared to that of diesel oil. These 
exhaust emissions were found to be close to diesel for preheated Jatropha oil. Brake specific fuel consumption and exhaust gas temperature were found higher compared to diesel oil. Non-edible filtered Jatropha, Karanja and Polanga oils based mono esters as biodiesel produced and blended with diesel oil were tested for their use as substitute fuels for diesel engines were investigated by P.K. Sahoo, and L. M. Das [15]. Biodiesel from unrefined Jatropha, Karanja and Polanga seed oils is quite suitable as an alternative to diesel fuel. Comparison of operational characteristics of diesel engine run with Jatropha biodiesel and diesel blends were performed by P. V. Rao [16]. Decrease in premixed combustion and increase in diffused combustion are observed with preheating of Jatropha biodiesel. With preheating oil, reduction in $\mathrm{NO}_{\mathrm{x}}$ emission and increase in soot emission is attributed to lower premixed combustion and higher diffusion combustion respectively. Soot emissions are reduced with preheating of Jatropha biodiesel.

In this study, two conversion Jatropha biodiesel processes such as esterification and transesterification were used for production of Jatropha methyl ester (JME) from crude oil. Jatropha biodiesel blends at lower percentages (5-20\% at regular intervals of 5\% on a volume basis), was blended with diesel fuel respectively. Several tests were conducted to characterize Jatropha biodiesel and its blends versus diesel in order to compare various physical and chemical properties. Viscosity and density of Jatropha methyl ester, its blends with diesel oil were measured at different temperatures to obtain the effect of temperature on its viscosity and density. Experiments were also performed using various blends of Jatropha biodiesel with diesel oil to study its effect on the performance, emissions and combustion characteristics of diesel engine. Performance parameters (specific fuel consumption, thermal efficiency, exhaust gas temperature and air- fuel ratio), exhaust emissions ( $\mathrm{CO}, \mathrm{HC}, \mathrm{NO}_{\mathrm{x}}$ and smoke) and combustion characteristics (cylinder pressure and heat release) for jatropha biodiesel blends were investigated. Comparisons of performance, emissions and combustion characteristics for Jatropha biodiesel blends and diesel fuel were done.

\section{Materials and Methods}

\subsection{Production of Jatropha Biodiesel}

In this study, base catalyzed transesterification is selected as the process to make biodiesel from Jatropha oil. A two stage process is used for biodiesel production Jatropha oil [16-18]. The first stage of the process is called esterification which is used to reduce the free fatty acid (FFA) content in Jatropha oil by esterification with methanol (99\% pure) and acid catalyst (sulfuric acid of $98 \%$ purity) in three hours reaction at $80{ }^{\circ} \mathrm{C}$. In the second stage, called transesterification, Jatropha oil is heated up to $70{ }^{\circ} \mathrm{C}$ in a round bottom flask to get off moisture and stirred vigorously. Triglyceride of Jatropha oil reacts with methanol of density $0.791 \mathrm{~g} / \mathrm{cm}^{3}$ and base catalyst (potassium hydroxide of $99 \%$ purity), which is dissolved in Methanol in molar ratio 6:1 and was poured into round bottom flask while stirring the mixture continuously. The mixture is maintained at atmospheric pressure and $65^{\circ} \mathrm{C}$ for 60 minutes to form methyl ester and glycerol. Triglyceride is converted stepwise to diglyceride, monoglyceride, and finally glycerol. Then the mixture is allowed to settle under gravity for 24 hours in a separating funnel. The products formed during biodiesel production were Jatropha oil methyl ester and glycerin. The bottom layer consists of glycerin, excess alcohol, catalyst, impurities and traces of unreacted oil. The upper layer consists of biodiesel, alcohol and some soap. The glycerol layer was separated and the raw fatty acid methyl ester (FAME) was water washed to remove unreacted methoxide by water washing with air-bubbling. It was then heated to remove the water traces to obtain clear biodiesel. This process resulted in $92 \%$ yield of Jatropha methyl ester. Jatropha biodiesel was blended with diesel fuel by volume percentages of $5,10,15$ and $20 \%$ manually due to insignificant variations in viscosity and density between Jatropha biodiesel and diesel fuel. 


\subsection{Characterization of Jatropha Biodiesel and its Blends}

The measurements of fuel properties of Jatropha oil and its blends in comparison with diesel fuel according to ASTM D 6751-02 [19] are shown in Table 1. Fuel properties of Jatropha methyl ester (JME) and its blends are comparable to those of diesel fuel. Transesterification process improved the fuel properties of the oil with respect to its density, calorific value, viscosity, flash point and pour point. Methyl esters of Jatropha have relatively closer property values to that of diesel fuel. Hence, no hardware modification are required for handling of biodiesel and its blends in the existing engine. Pour points of biodiesel blends are higher than for diesel fuel due to its higher carbon to hydrogen ratio and lower volatility of biodiesel fuel. The ash content of biodiesel fuel is lesser than diesel fuel. Jatropha biodiesel has higher density than diesel fuel. The fuel with lower energy content per liter will cause the engine to produce less peak power and the higher density of biodiesel compensates the lower energy content [20]. The greatest difference in using Jatropha oil as compared to diesel fuel is the higher viscosity of the oil, which could contribute to higher carbon deposits in the engine and cause some durability problems. The higher cetane number and calorific value of biodiesel that are near to diesel fuel make it possible to use in diesel engines. The flash point of Jatropha biodiesel and their blends is lowered by transesterification but still higher than that of diesel oil. Addition of a small percentages of biodiesel with diesel increases the flash point. Biodiesel is safer to store, use and handle than petroleum diesel fuel. The calorific values of Jatropha biodiesel and its blends are lower than that of diesel oil. Biodiesel heating value lies in the range of 39-40 MJ/kg, which is comparatively lower than that of diesel fuels (about 42 $\mathrm{MJ} / \mathrm{kg}$ ). This is because of the presence of chemically bonded oxygen in vegetable oils lowers the heating value by about $10 \%$. The cetane number is in the range of 50-58.

The main problem of using Jatropha oil in conventional diesel engine is its higher viscosity. Therefore, it is necessary to reduce the fuel viscosity before injecting it in the engine. Higher viscosity of Jatropha oil can be reduced by preheating the oil using waste heat of exhaust gases from the engine and also by blending the Jatropha oil with diesel oil. In this study, viscosity and density of Jatropha oil and diesel fuel were measured at different temperatures in the range of $40-100^{\circ} \mathrm{C}$ to find the effect of temperature on viscosity and density of the tested fuels. Each measurement is recorded at least three times to ensure the reproducibility. The variation of viscosity and density values for the studied fuels versus temperature are shown in Fig.1. Fuel density is linearly decreased while viscosity is exponentially decreased with the increase of fuel temperature. Viscosity of diesel, biodiesel, and blended fuels is decreased as the temperature increased because the intermolecular attraction between different layers of the fuel becomes weak. Viscosity of Jatropha oil decreases with increasing temperature and it becomes close to diesel fuel at temperature above $90^{\circ} \mathrm{C}$. As observed from Table 1 and Fig.1, the properties of vegetable oils differ from those of transesterified oils forming biodiesel. Viscosity and density of diesel fuel are lower than those of jatropha biodiesel fuels due to the removal of glycerin and heavy waxes within raw oils. The maximum difference between viscosities of B5, B10, B15, B20 and D100 are obtained at $40^{\circ} \mathrm{C}$. Biodiesel should be heated to $90-100^{\circ} \mathrm{C}$ In order to bring physical properties of biodiesel close to diesel fuel at normal temperature of $30^{\circ} \mathrm{C}$. Fuels densities decreased with the increase of temperature. The density of B5, B10, B15 and B20 biodiesel blends are close to that of neat diesel fuel. The effect of preheating temperature on the viscosity and density of biodiesel and its blends are comparable with those cited in the literature [21, 22]. 

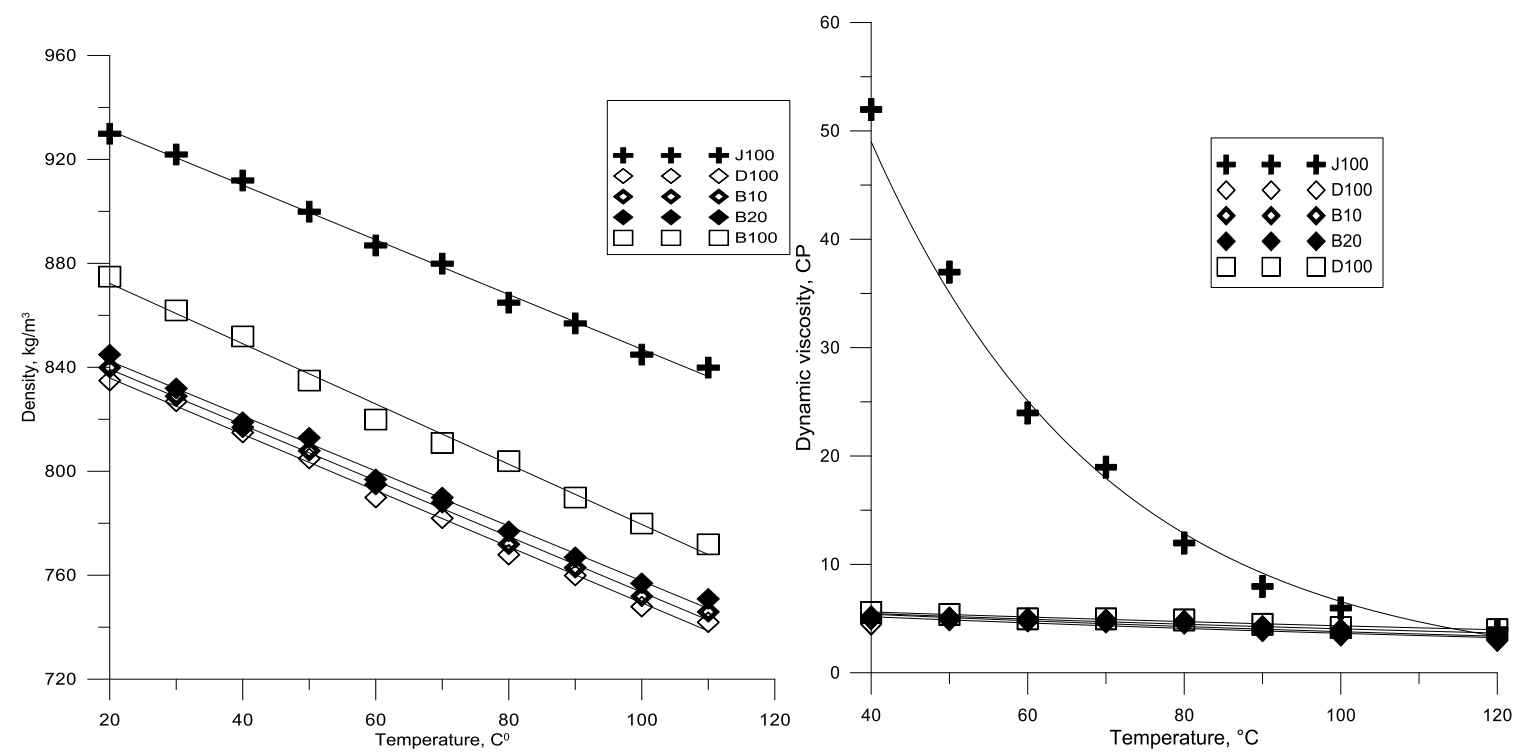

Fig.1.: Viscosity and density of different fuels versus temperature.

Table 1: Fuel properties (diesel fuel, Jatropha methyl ester and its blends)

\begin{tabular}{l|c|c|c|c|c}
\hline \multirow{2}{*}{\multicolumn{1}{c|}{ Properties }} & \multirow{2}{*}{ Method } & \multicolumn{4}{c}{ Oil } \\
\cline { 3 - 6 } & & Diesel & Jatropha & JME100 & JMEB20 \\
\hline \hline Dynamic viscosity, at $40^{\circ} \mathrm{C}, \mathrm{cp}$ & ASTMD445 & 4.5 & 52 & 5.6 & 5.2 \\
\hline Heating value $\mathrm{MJ} / \mathrm{kg}$ & ASTMD270 & 42.1 & 36.56 & 39.52 & 40.0 \\
\hline Density, at $15^{\circ} \mathrm{C} \mathrm{kg} / \mathrm{m}^{3}$ & ASTMD1298 & 825 & 930 & 875 & 845 \\
\hline Cetane number & ASTMD613 & 50 & 40 & 58 & 53 \\
\hline Flash point, ${ }^{\circ} \mathrm{C}$ & ASTMD92 & 77 & 234 & 164 & 88 \\
\hline Pour point, ${ }^{\circ} \mathrm{C}$ & ASTMD97 & -17 & -7 & -8 & ----- \\
\hline Cloud point, ${ }^{\circ} \mathrm{C}$ & ASTMD97 & -12 & -1 & -4 & ----- \\
\hline \hline
\end{tabular}

\section{Experimental Setup}

\subsection{Engine Setup}

The experimental tests were carried out using a single cylinder, four stroke, air cooled, direct injection, naturally aspirated, constant compression ratio, diesel engine with a developing power of $5.775 \mathrm{~kW}$ at $1500 \mathrm{rpm}$ at National Research Centre, Engine Research lab., Egypt. Technical specifications of the engine are given in Table 2, and the schematic diagram of the experimental arrangement is shown in Fig. 2. AC generator of maximum electric output power of $10.5 \mathrm{~kW}$ equipped with a load controller and have been coupled directly to the test engine to determine the engine output brake power. The intake airflow was measured by a sharp edged orifice mounted in the side of an air box, coupled to the engine intake to dampen the pulsating airflow into the engine. A $U$ tube manometer was used to measure the pressure drop across the orifice. Calibrated thermocouple probes of type $(\mathrm{K})$ were used for temperature 
measurements at different locations in the experimental set up; including: intake air manifold and exhaust gas. A selecting switch is used to switch among these thermocouples and the signals are readout by a digital thermometer. The crankshaft rotational speed was measured using speed tachometer. Two fuel tanks of 10 Liters capacity were mounted for storing the fuels on the rear side of the panel at highest position. One burette with stopcock and two way valves were mounted on the front side of the panel for fuel flow measurements and selecting between both diesel and biodiesel fuels. Fuel consumption was determined by measuring the time for the consumption of fixed fuel volume $(20 \mathrm{ml})$. The instantaneous in cylinder pressure was measured by a water cooled Kistler piezoelectric pressure transducer (model 601A) measure from 0 to 250 bar as pressure range with sensitivity of $16.5 \mathrm{pc} / \mathrm{bar}$ and accuracy of $1.118 \%$ connected with Nexus conditioning charge amplifier (2692-A-0S4). The piezoelectric pressure transducer was flush mounted with the cylinder head to measure the engine in cylinder pressure. Flush mounting was preferred to minimize the lag in the pressure signal and avoid pipe connecting passage resonance. The instantaneous position of the piston top dead center (TDC) was determined using a proximity switch (Type LM12-3004PA) fixed on the output shaft of the engine. In order to guarantee confidence in the combustion diagnosis results, the combustion pressure data were averaged over 120 consecutive engine cycles. In all the cases, the pressure crank angle diagrams were recorded and processed to get the combustion parameters by the data acquisition system. High speed data was acquired using LabVIEW software and national instruments data acquisition card (NI-USB-6210) for later analysis. OPA 100 smoke meter and MRU DELTA 1600-V Gas Analyzer were used for the measurements of various exhaust gases concentrations. The accuracy and reproducibility of the instrument was $\pm 1 \%$ of full scale reading. The measurement principle for $\mathrm{CO}, \mathrm{HC}, \mathrm{CO}_{2}$ was infrared measurement and for $\mathrm{NO}$ and $\mathrm{O}_{2}$ it was electrochemical measurement. Digital readouts of $\mathrm{CO}, \mathrm{NO}_{\mathrm{X}}, \mathrm{HC}, \mathrm{CO}_{2}$ and $\mathrm{O}_{2}$ are available through the analyzer screen after steady state condition and the average was taken for fifth minutes. Tests were executed without carrying out any modification on the engine or its fuel injection system. The experiment was carried out by varying load from 20 to $100 \%$ by maintaining constant speed of $1500 \mathrm{rpm}$ throughout the tests. The injection timing was $24^{\circ}$ BTDC at an injection pressure of $175 \mathrm{bar}$ and compression ratio was 17.5:1. The engine run was conducted as specified by IS 10,000. The performance and emission measurements were triplicated. All the equipment's were calibrated in accordance to the respective manufacturer's specifications, prior to conducting the tests. All the tests are carried out for three times under steady state conditions.

Table 2: Engine specifications

\begin{tabular}{l|l}
\hline \hline Engine parameters & Specifications \\
\hline Type & DEUTZ F1L511 \\
\hline Number of cylinders & 1 \\
\hline Number of Cycles & Four stroke \\
\hline Cooling type & Air cooled \\
\hline Bore $(\mathrm{mm})$ & 100 \\
\hline Stroke $(\mathrm{mm})$ & 105 \\
\hline Compression ratio & $17.5: 1$ \\
\hline Fuel injection advance angle & $24^{\circ}$ BTDC \\
\hline Rated brake power $(\mathrm{kW})$ & 5.775 at $1500 \mathrm{rpm}$ \\
\hline Number of nozzle holes & 1 \\
\hline Injector opening pressure (bar) & 175 \\
\hline \hline
\end{tabular}




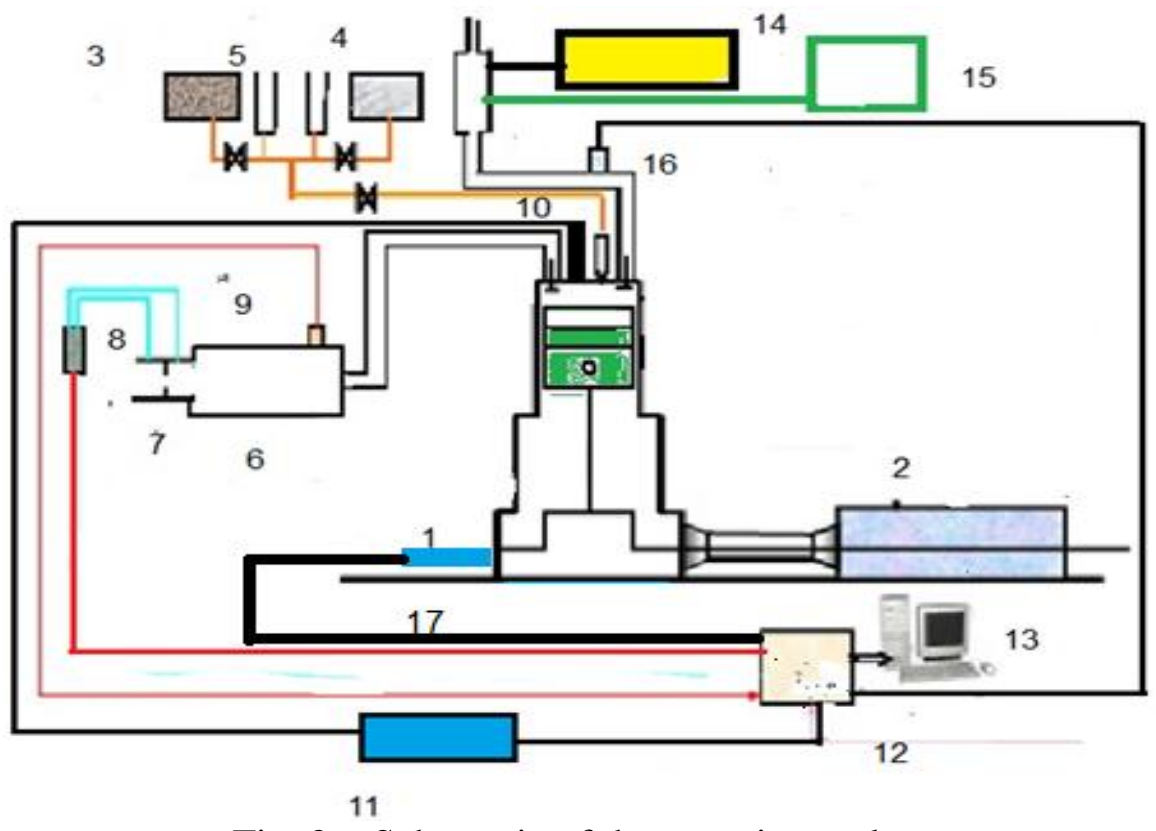

Fig. 2: Schematic of the experimental setup

1-Diesel Engine, 2- AC generator, 3- Diesel tank, 4- Biodiesel tank, 5- Burette, 6- Surge air tank, 7- Orifice, 8- Pressure differential meter, 9- Intake air temperature sensor, 10- Piezo pressure transducer, 11- Charge amplifier, 12- Data acquisition card, 13- Personal computer, 14- Exhaust gas analyzer, 15- Smoke meter, 6- Exhaust gas temperature sensor, 17- TDC marking switch

\section{Results and Discussion}

\subsection{Effect of Biodiesel Blends on Engine Performance}

\subsubsection{Effect of biodiesel blends on brake specific fuel consumption}

Variation of BSFC with respect to engine load variation for Jatropha methyl ester blends and diesel fuel is shown in Fig. 3. Brake specific fuel consumption of Jatropha biodiesel blends is higher at all levels of power output compared to diesel fuel. The trends of biodiesel blends showed an increase in fuel consumption proportional to the amount of Jatropha oil biodiesel added to diesel fuel. There were about 1.6, 7.5, 14.5 and 16.5\% higher percentages of specific fuel consumptions when running on B5, B10, B15, and B20 in comparison to diesel fuel at full load, respectively. This was due to more percentage of oxygen, less percentage of hydrocarbons and lower calorific value of jatropha methyl ester blends about diesel fuel. The net calorific value of the Jatropha oil biodiesel is about $14.88 \%$ lower than that of diesel fuel. The engine consumes more fuel than compared to diesel fuel to develop the same power. Fuel density has importance in diesel engine performance since the fuel injection system operates on a volume metering system [23]. Jatropha biodiesel has higher density than diesel fuel as shown in Table 1. Higher density of biodiesel compensated the lower energy content is attributable to advance of fuel injection timing due to higher bulk modulus of compressibility in the inline fuel injection system. The bulk modulus of jatropha biodiesel is more than that of diesel fuel. The bulk modulus of jatropha biodiesel is $1800 \mathrm{MPa}$ as compared to that of 1475 MPa for diesel fuel. The pressure waves generated by the pump plunger traveled faster from pump end to the fuel injector needle, caused an earlier needle lift and early fuel injection [2431]. Moreover, as the Jatropha biodiesel percentage increased in Jatropha biodiesel blends and the injection timing was advanced. This is due to higher density of biodiesel, speed of sound and bulk modulus led to a faster increase in injection pressure [32-36]. It was necessary to 
increase the acceleration (due to the lower heating value of biodiesel) to guarantee the same brake output power with all fuels. The injection pump (volumetric type) had to change its operating point although the engine speed and torque were maintained constant (maintaining the engine operation mode) since it had to inject more fuel at the same engine speed and so it had to start delivering fuel earlier.

\subsubsection{Effect of biodiesel blends on brake thermal efficiency}

Brake thermal efficiency is one of the most important engine performance parameter, which indicates the percentage of fuel energy converted to useful power output. Figure 3 illustrated the variation in the brake thermal efficiency with load variation of the engine for diesel fuel and different Jatropha biodiesel blends in the ratio of 5, 10, 15 and 20\% with diesel fuel. From Fig.3, the thermal efficiency of diesel oil and JME blends increase with increasing in engine brake power. As the brake power increases the heat generated in the cylinder increases, and hence, the thermal efficiency increases. Brake thermal efficiency is slightly lower for JME blends compared to diesel fuel at all engine loads. Brake thermal efficiency for diesel fuel is $30.9 \%$ at full load and the highest among all the fuels tested. Thermal efficiencies for jatropha biodiesel blends JB5, JB10, JB15 and JB20 are 30.7, 30.3, 28.4 and 27.3\%, respectively at full load. There were decreases in brake thermal efficiency of biodiesel blends compared to diesel fuel. The drop in thermal efficiency must be attributed to the poor combustion characteristics of methyl esters due to lower calorific values, higher densities, higher viscosities and poor volatilities of JME and its blends as compared to diesel fuel [23].
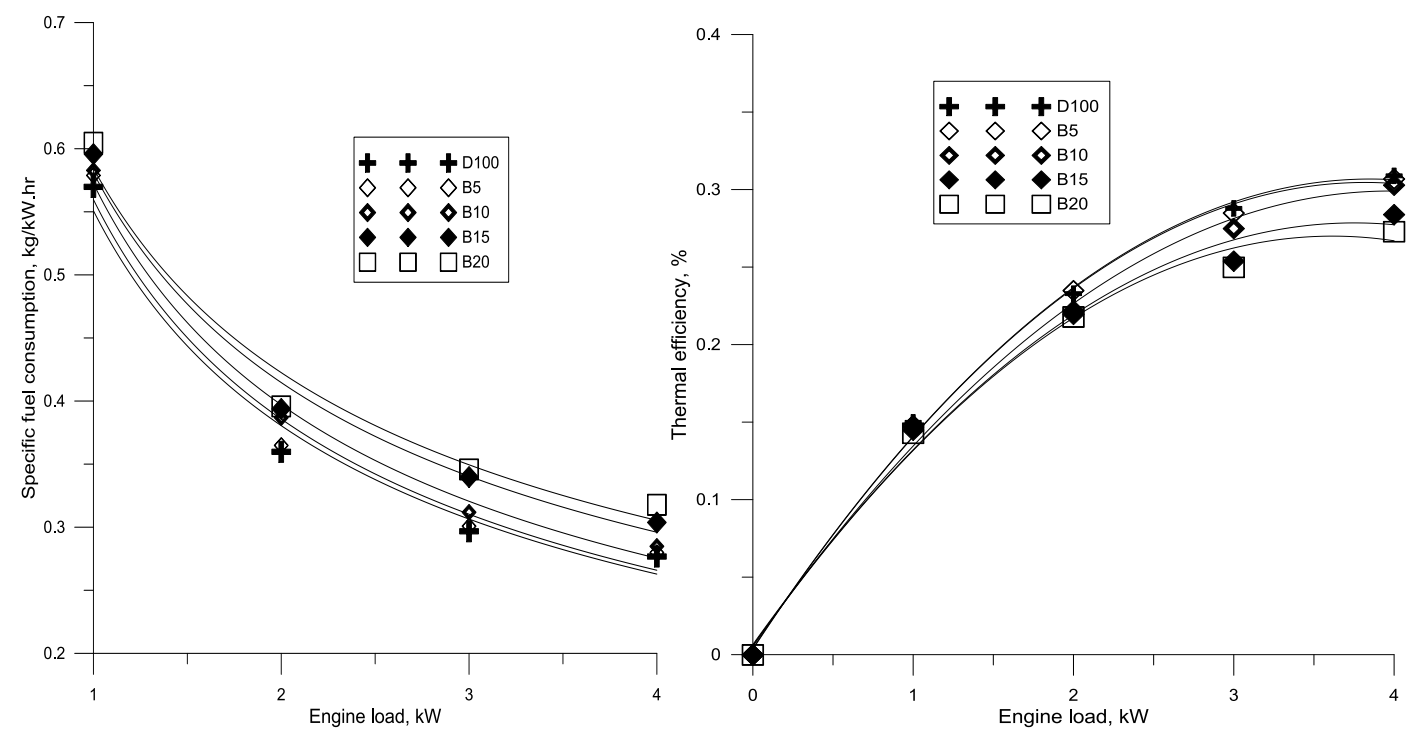

Fig.3.: Variation of specific fuel consumption and thermal efficiency with brake power.

\subsubsection{Effect of biodiesel blends on exhaust gas temperature (EGT)}

Temperature of exhaust gases leaving the cylinder reflects on the status of combustion inside the combustion chamber. Exhaust gas temperature represents the extent of temperature reached during combustion and gives an indication about the amount of heat going and wasted in the exhaust gases. Figure 4 illustrates the variation of the exhaust gas temperature with respect to engine brake power. The exhaust gas temperature increased with increase in engine load and amount of biodiesel in biodiesel blends. As a result of the poor combustion characteristics, increased combustion duration, higher exhaust gas temperature is recorded for Jatropha biodiesel blends as compared to diesel fuel for the entire range of engine power output [37]. 


\subsubsection{Air- Fuel equivalence ratio $(\lambda)$}

Effect of engine load variation on air- fuel equivalence ratios for biodiesel blends were investigated in Fig.4. Air- fuel ratios decreased with the increase in engine loads due to the increase of fuel consumption and the richer mixture at higher engine loads. Fuel consumptions were higher for biodiesel blends B5, B10 and B20 compared to diesel fuel, so air-fuel equivalence ratios decreased. Air- fuel equivalence ratio decreased with increase of biodiesel content due to increase of fuel consumption. The oxygen content of biodiesel and its blends led to a slight reduction of air- fuel equivalence ratio from 1.96 (diesel oil) to 1.5 (biodiesel blend B20) at full load.
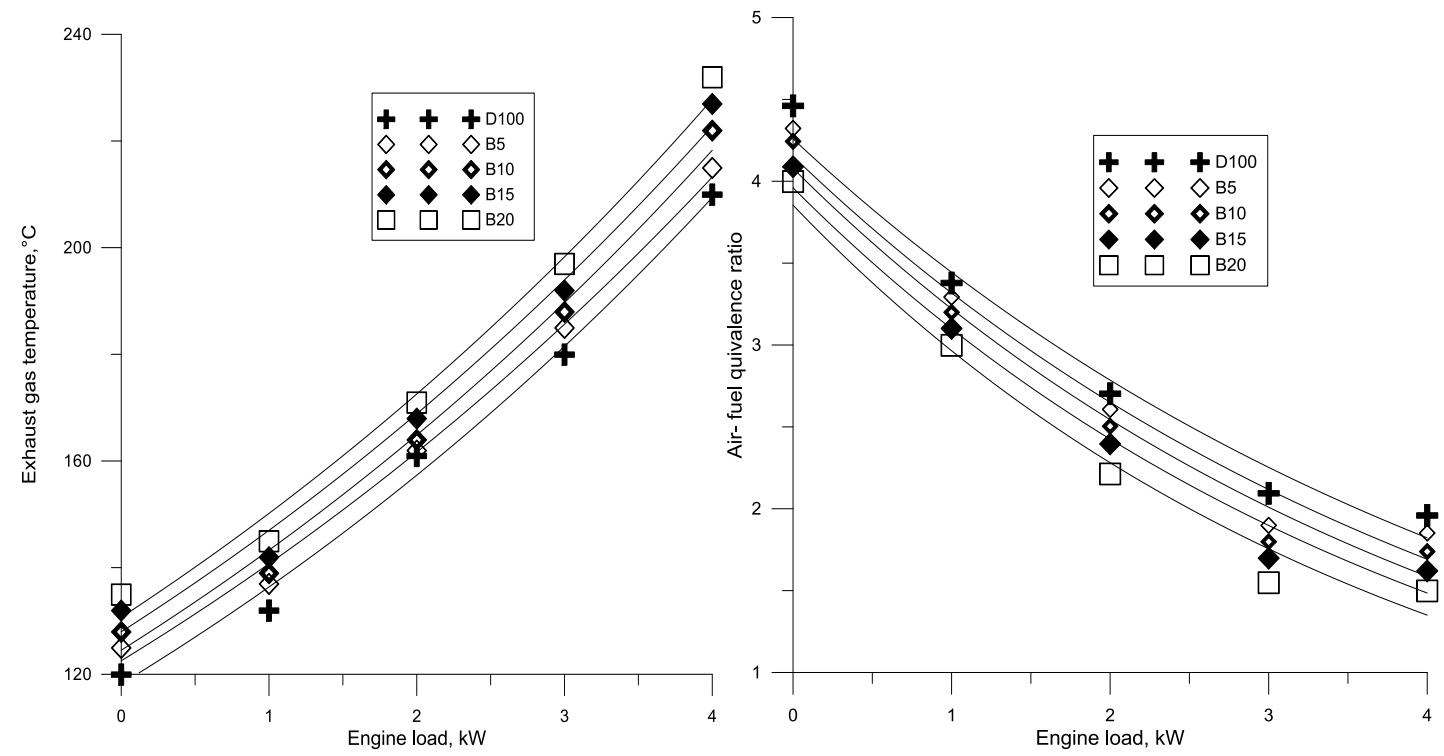

Fig.4.:Variation of exhaust gas temperature and air- fuel ratio with brake power.

\subsection{Effect of Biodiesel Blends on Exhaust Emissions}

\subsubsection{Effect of biodiesel blends on carbon monoxide (CO) emission}

$\mathrm{CO}$ emissions are low for diesel engines as they are operated under lean mixtures, a decrease in $\mathrm{CO}$ emissions when substituting diesel fuel with biodiesel can be considered [38, 39, 40, 41]. Figure 5 shows the trend of CO emission for diesel fuel and JME blends with respect to engine brake power. $\mathrm{CO}$ emission decreases with increase in brake output power. $\mathrm{CO}$ emissions in diesel engines are reduced by use of Jatropha methyl ester blends. As volume percentage of methyl ester in the fuel increases, $\mathrm{CO}$ is reduced within the whole experimental range. Values of CO emissions for diesel fuel, JMEB5, JMEB10, JMEB15 and JMEB20 are $0.039,0.037,0.036,0.034$ and $0.029 \%$ respectively, at full load operation. The decrease in $\mathrm{CO}$ emission for Jatropha biodiesel is attributed to the presence of oxygen in the molecular structure of jatropha biodiesel that is helpful for better combustion, thus reducing the $\mathrm{CO}$ emissions and due to the higher cetane number that reduces the probability of fuel-rich zones formation $[38,39,42]$.

\subsubsection{Effect of biodiesel blends on hydrocarbon (HC) emission}

Hydrocarbon emission is mainly due to incomplete combustion. Figure 5 showed the variation of $\mathrm{HC}$ emission with respect to engine output brake power for various Jatropha biodiesel blends and diesel fuel. $\mathrm{HC}$ emission is lower at engine part load, but it tends to increase for all the test fuels as the engine load increases. This is perhaps due to the presence of fuel rich mixture due to lack of oxygen resulted from engine operation at higher fuel- air equivalence ratio. Higher percentage of oxygen leads to lower $\mathrm{HC}$ emission at higher engine 
brake power. There are slightly reductions in HC emissions for Jatropha methyl esters blends with diesel fuel at all engine loads compared to diesel fuel. Adding methyl ester to diesel fuel increases oxygen content resulting in better combustion, and lower $\mathrm{HC}$ emissions. Values of HC emissions for JMEB5, JMEB10, JMEB15,JMEB20 and diesel fuel are 22, 18, 17, 15 and $13 \mathrm{ppm}$, respectively at full load operation. Increasing the percentage of Jatropha methyl ester in the fuel drastically reduces HC emissions due to the higher cetane number and inherent presence of oxygen in the molecular structure of the jatropha biodiesel.
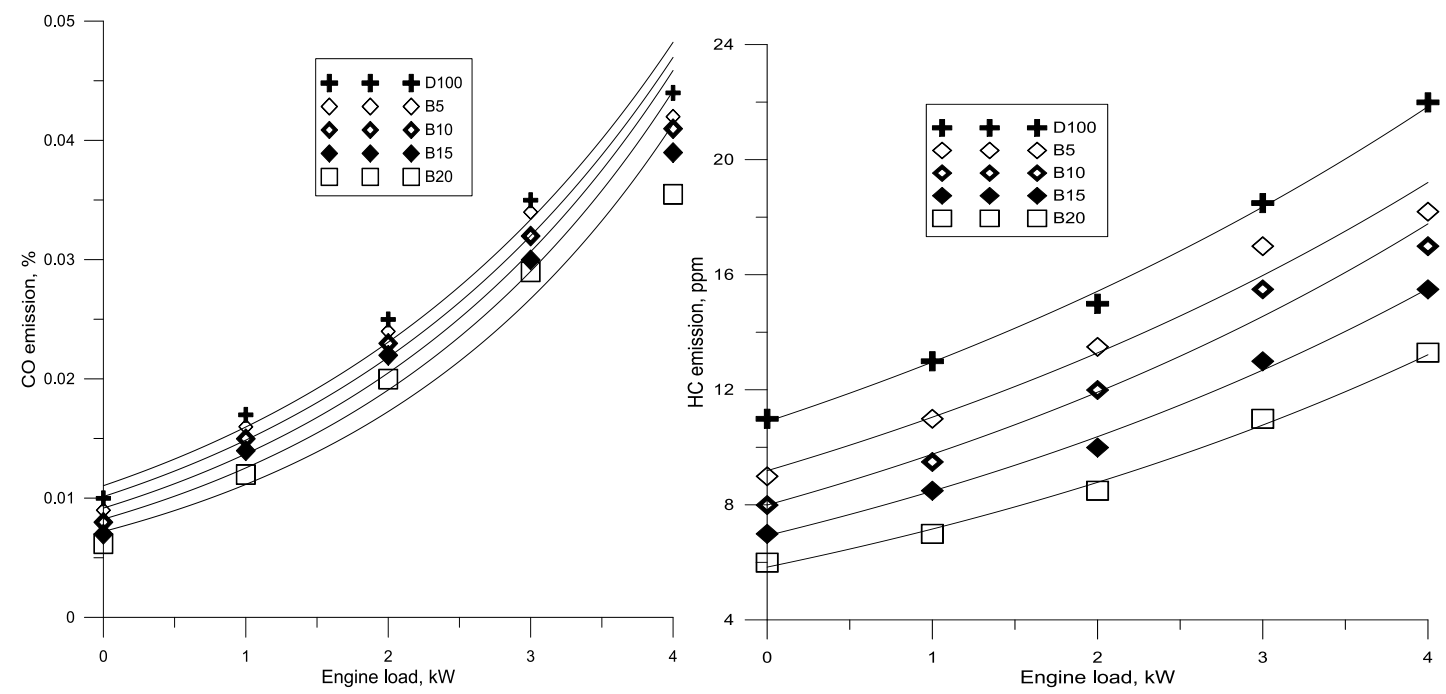

Fig.5.:Variation of carbon monoxide and hydrocarbon with engine load.

\subsubsection{Effect of biodiesel blends on nitrogen oxides (NOx) emissions}

Two important factors affecting the formation of $\mathrm{NO}_{\mathrm{x}}$ in diesel engine are cylinder combustion temperature and the availability of oxygen. Variation of NOx emissions from Jatropha methyl ester and its blends with respect to diesel fuel are shown in Fig.6. NOx emissions increased with the increase in engine load for all the test fuels. The increased engine load promoting NOx emission. Formation of NOx is very sensitive to cylinder temperature. This is due to increase in the amount of fuel burned with engine load, which results in increase of cylinder temperature which is responsible for thermal (or Zeldovich) NOx formation. NOx emissions for Jatropha biodiesel and its blends are higher than that of diesel fuel within the entire range of engine loading. Adiabatic flame temperature is slightly higher for biodiesel because of its oxygenated nature and help for more complete combustion, higher cylinder temperature and NOx emission. Biodiesel contains more double bonded molecules than diesel fuel, these double bonded molecules have a slightly higher adiabatic flame temperature which leads to increase in NOx production for biodiesel. The fuel spray properties may be altered due to differences in viscosity and surface tension. The spray properties affected may include droplet size, droplet momentum, degree of mixing, penetration, and evaporation. The change in these properties might be lead to different relative duration of premixed and diffusive combustion regimes, the two burning processes have different emission formation characteristics. The shorter ignition delay and increased amount of biodiesel undergoing premixed combustion results in higher cylinder pressure and cylinder temperature. Rate of NOx formation in diesel engines is a function of flame temperature which is closely related to the peak cylinder pressure and temperature. Combustion takes place over a shorter period and allows less time for cooling by heat transfer and dilution [4345]. The above reasons can explain the higher NOx formation associated with the combustion of biodiesel. Values of NOx emission for diesel, JMEB5, JMEB10, JMEB15, and JMEB20 are 182,197, 210, 222 and 240 ppm respectively, at full load operation. Emissions of nitrogen oxides $\left(\mathrm{NO}_{\mathrm{X}}\right)$ increase with increase in percentage of Jatropha methyl ester in biodiesel blend are observed. Jatropha methyl esters are oxygenated fuels and more oxygen is available for 
formation of $\mathrm{NOx}$ compared to diesel fuel. $\mathrm{NO}_{\mathrm{X}}$ emissions increase with increase in percentage of methyl esters in the blends [46, 47-53].

\subsubsection{Effect of biodiesel blends on smoke emissions}

Smoke is the result of incomplete combustion and is formed in the rich mixture zone [54]. Figure 6 illustrates the smoke emission for the tested fuels. The results show that smoke emissions increase with increase in engine output power for all fuels. This increasing trend is due to the increase in fuel consumption with the output power, presence of branched and ring (multi ring or poly) structures of diesel fuel which increase the smoke levels [55]. Smoke opacities from Jatropha methyl ester and its blends are lower than diesel fuel under similar operating conditions. This is probably possible because of the higher cetane number and inbuilt oxygen of biodiesel fuel, which results in better combustion resulting in reduction of smoke opacity. The smoke opacity values for diesel, JMEB5, JMEB10, JMEB15, and JMEB20 are 78, 72, 68, 64 and 60\%, respectively, at full load. Smoke density decreases with increase in methyl ester in biodiesel blend. The reduce in smoke emissions of methyl esters can be attributed to its lower aromatic and short chain paraffin hydrocarbons and higher oxygen content $[47-53,56]$.
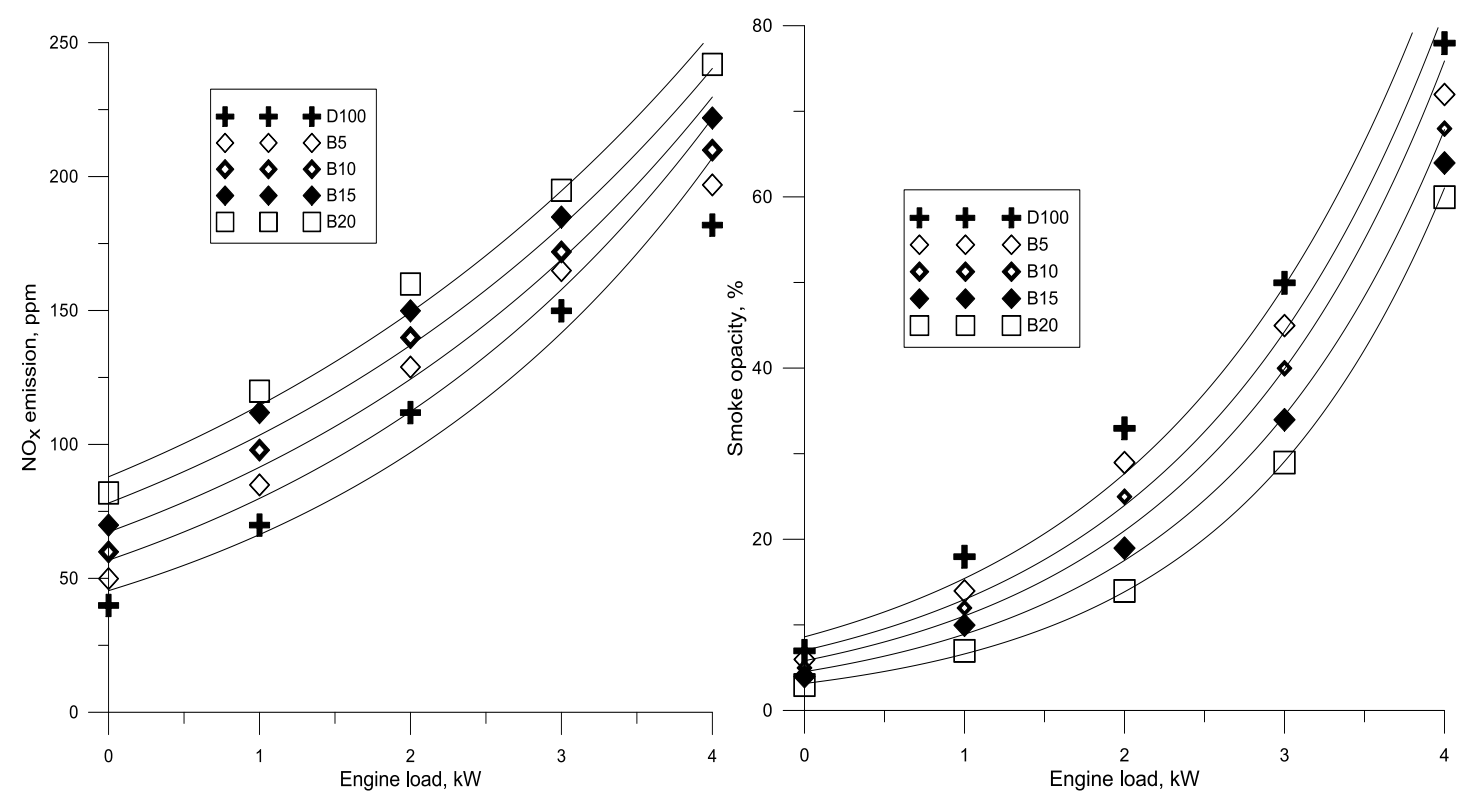

Fig.6.:Variation of nitrogen oxides and smoke opacity with brake power.

\subsection{Effect of Biodiesel Blends on Combustion Characteristics}

\subsubsection{Variation of cylinder pressure with crank angle}

Cylinder pressure characterizes the ability of the fuel to mix with air and burn well. High peak pressure and maximum rate of pressure rise correspond to large amount of fuel burnt in premixed combustion stage. Figure7 showed the variation of cylinder pressure with crank angle for diesel, Jatropha methyl esters and their blends. Jatropha methyl esters and their blends follow a cylinder pressure pattern similar to diesel fuel at full load. The cylinder pressure is lower for biodiesel and its blends compared to diesel fuel and decreases with increase in percentage of methyl ester in the blends. This is due to higher cetane number of jatropha biodiesel and its blends, shorter ignition delay and more fuel burnt in diffusion stage. Cylinder pressure depends on the burnt fuel fraction during premixed burning phase. 


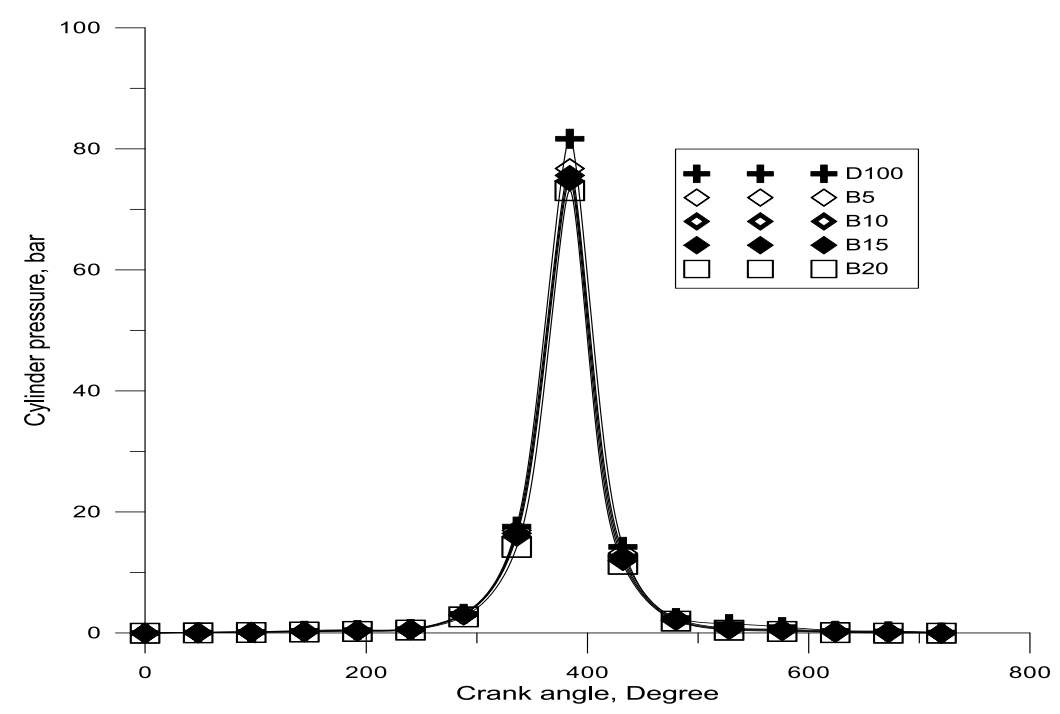

Fig.7. Variation of cylinder pressure with crank angle for diesel, Jatropha methyl esters and their blends at full load.

\subsubsection{Variation of heat release rate with crank angle}

Figure 8 illustrated the heat release rate with respect to the crank angle at full load. The heat release rate of diesel, Jatropha methyl esters and their blends show similar patterns. The peak of heat release rates of Jatropha methyl esters and their blends are lower than that of diesel fuel and decreases as the percentages of methyl ester in biodiesel blend increases. Due to the shorter ignition delays and higher viscosities compared to diesel fuel at full load. The ignition quality of the fuel is characterized by its cetane number. Higher cetane number generally means shorter ignition delay. Jatropha methyl esters and their blends have higher cetane number than diesel fuel. Shorter ignition delay causes lower peak heat release rate due to lower accumulation of the fuel. Premixed combustion heat release is higher for diesel fuel that is responsible for higher peak cylinder pressure and higher rate of pressure rise in comparison to biodiesel fuel.

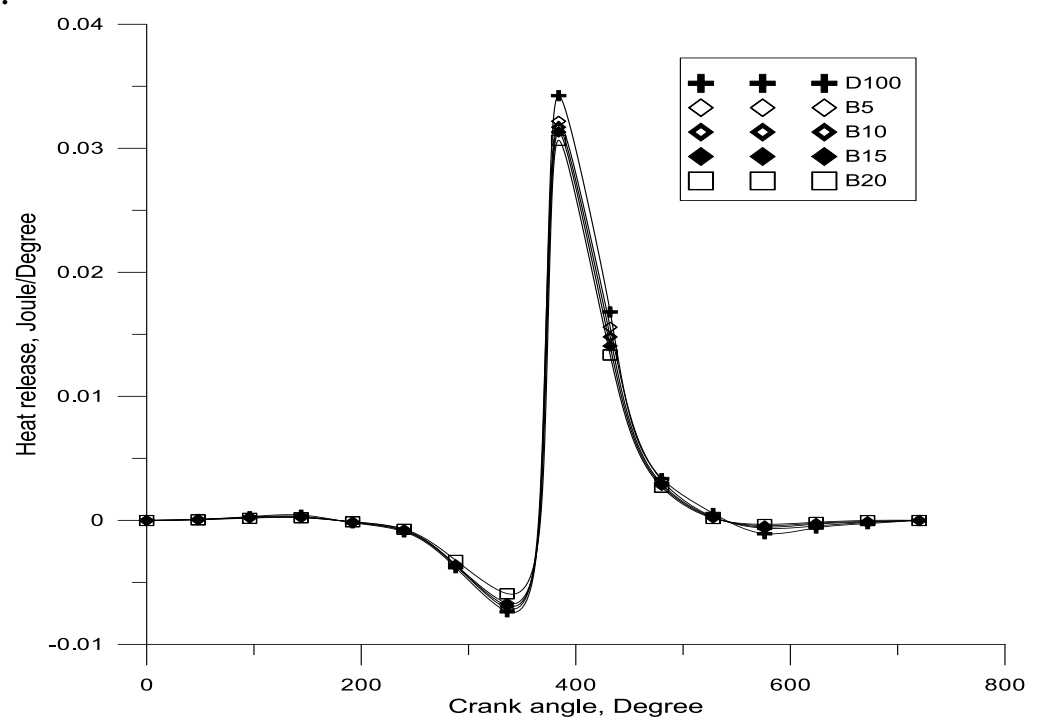

Fig.8.:Variation of heat release rate with crank angle for diesel, Jatropha methyl esters and their blends at full load.

\subsubsection{Effect of biodiesel blends on peak cylinder pressure}

Variation of the cylinder peak pressure at different engine brake output power is shown in Fig. 9. The peak cylinder pressure increases with increase in engine brake load for all the test fuels. This is due to that more fuel is burned at higher engine loads. Jatropha methyl ester and its blends record lower peak cylinder pressures compared to diesel fuel at all engine loads and 
decreases as the percentages of methyl ester in the blends increases. The decrease in peak cylinder pressure compared to diesel fuel at full load is due to the lower calorific value of biodiesel blends and poor atomization. More diesel fuel might be accumulated in the delay period as a result of longer ignition delay and higher cylinder peak pressure for diesel fuel than for methyl ester and its blends.

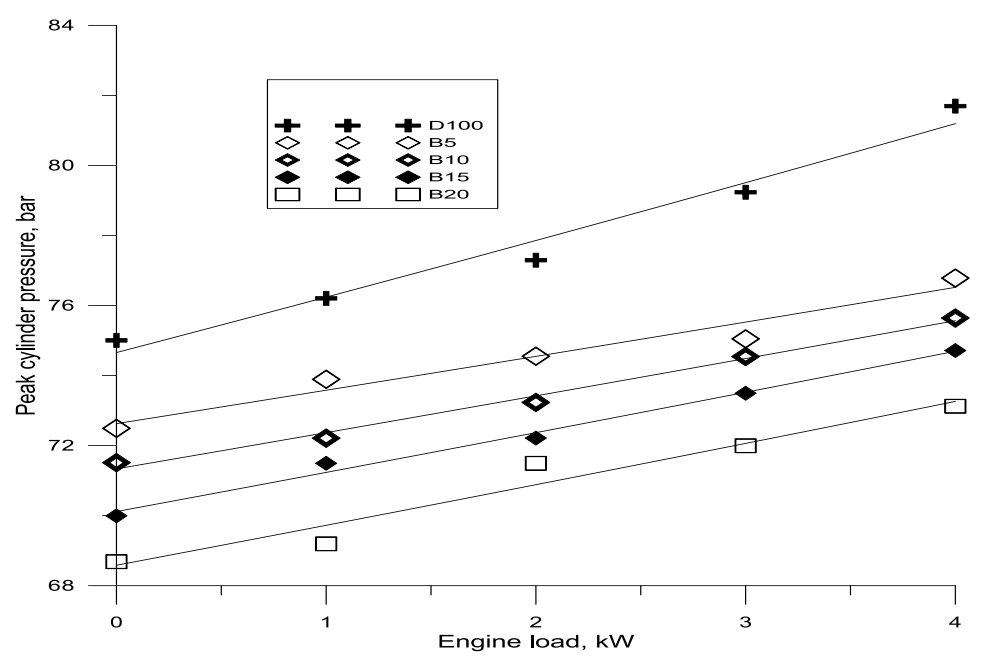

Fig.9. :Peak cylinder pressure at different engine loads for diesel, Jatropha methyl esters and their blends at full load.

\section{Conclusions}

These conclusions based on the experimental results obtained while operating engine tests on unmodified single cylinder diesel engine fuelled with biodiesel from Jatropha oil and their blends with fossil diesel.

1. Addition of Jatropha biodiesel to diesel fuel changes the physical and chemical properties of the blends. With the increase of biodiesel concentration in diesel biodiesel blends density, kinematic viscosity, cetane number, higher heating value, flash and pour point of the blends increase.

2. Biodiesel blends should be preheated up to $70-80^{\circ} \mathrm{C}$ to compensate the effect of higher viscosity of Jatropha biodiesel blends as compared to diesel fuel at normal temperatures.

3. Engine performance with biodiesel of Jatropha blends with fossil diesel were comparable to the performance with neat diesel fuel. Oxides of nitrogen and exhaust gas temperature for Jatropha biodiesel blends were higher than diesel fuel. CO, smoke density and $\mathrm{HC}$ emissions were reduced for biodiesel blends as compared to diesel oil.

4. Brake thermal efficiency of Jatropha methyl ester blends with diesel fuel were lower compared to diesel oil and brake specific fuel consumption was found to be higher.

5. Biodiesel from non-edible oil like Jatropha could be a good substitute fuel for conventional diesel engine without any engine modification. Further research and development on prediction of best blend with respect to the various engine parameters such as long term run and wear analysis of biodiesel fueled engine is also necessary along with engine hardware modification.

\section{References}

[1] Balat M., "Current alternative engine fuels", Energy Sources 2005, 27(6): 569-77.

[2] Lu HF, Liu YY, Zhou H, Yang Y, Chen MY, Liang B., "Production of biodiesel from Jatropha curcas L. oil",Computers and Chemical Engineering 2009; 33(5): 1091-6. 
[3] Kumara G, Kumarb D, Joharia R, Singhb CP.,"A continuous transesterification process of Jatropha curcas oil in the presence of biodiesel as a green solvent", Bioresource Technology 2010, doi:10.1016/j.biortech.2010.07.123.

[4] Achten WMJ, Verchot L, Franken YJ, Mathijs E, Singh VP, Aerts R, et al., "Jatropha bio-diesel production and use", Biomass and Bioenergy 2008; 32(12):1063-84.

[5] Sahoo PK, Das LM, Babu MKG, Arora P, Singh VP, Kumar NR, et al.," Comparative evaluation of performance and emission characteristics of Jatropha, Karanja and Polanga based biodiesel as fuel in a tractor engine", Fuel 2009; 88(9):1698-707.

[6] Basha SA, Gopal KR, Jebaraj S., "A review on biodiesel production, combustion, emissions and performance", Renewable and Sustainable Energy Reviews 2009; 13(67):1628-34.

[7] Bozbas K., "Biodiesel as an alternative motor fuel: production and policies in the European Union", Renewable and Sustainable Energy Reviews 2008; 12(2):542-52.

[8] P.Q. Tan, Z.Y. Hu, D.M. Lou, and Z.J. Li, "Exhaust emissions from a light-duty diesel engine with Jatropha biodiesel fuel", Energy, vol. 39, pp. 356-362, 2012.

[9] S. Jain, and M. P. Sharma, "Study of oxidation stability of Jatropha curcas biodiesel / diesel blends", Energy and Environment, Vol. 2, pp. 533-542, 2011.

[10] Venkata Ramesh Mamilla, M.V.Mallikarjun, Dr. G.Lakshmi Narayana Rao., "Effect of combustion chamber design on a DI diesel engine fuelled with Jatropha Methyl Esters Blends with diesel", Procedia Engineering 64 ( 2013 ),479 - 490.

[11] Syarifah Yunusa, Amirul Abd Rashida, Nik Rosli Abdullaha, Rizalman Mamatb, Syazuan Abdul Latipa, "Emissions of transesterification Jatropha-Palm blended biodiesel" Procedia Engineering, 68 (2013), 265 - 270.

[12] Jindal S, Nandwana BP, Rathore NS, Vashistha V.," Experimental investigation of the effect of compression ratio and injection pressure in a direct injection diesel engine running on Jatropha methyl ester", Applied Thermal Engineering 2010; 30(5):442-8.

[13] Huang J, Wang Y, Qin J-b, Roskilly AP., "Comparative study of performance and emissions of a diesel engine using Chinese pistache and Jatropha biodiesel", Fuel Processing Technology 2010:017.

[14] Deepak Agarwal, and Avinash Kumar Agarwal," Performance and emissions characteristics of Jatropha oil (preheated and blends) in a direct injection compression ignition engine", Applied thermal Engineering 2007, 27(13), 2314-23.

[15] P.K. Sahoo, L. M. Das, "Process optimization for biodiesel production from Jatropha, Karanja and Polanga oils", Fuel 88 (2009) 1588-1594.

[16] P. V. Rao," Experimental investigations on the influence of properties of Jatropha biodiesel on performance, combustion and emission characteristics of a DI-CI engine", World Academy of Science, Engineering and Technology, 752011.

[17] Jon Van Gerpen, "Biodiesel Production and Fuel Quality", University of Idaho, Moscow, ID 83844., 2005.

[18] Tapasvi, D. Wiesenborn, D. and Gustafson, C.,"Process Model for Biodiesel Production from Various Feedstocks" Transactions of the ASAE, ISSN 0001-2351, Vol. 48(6):2215-2221, 2005.

[19] ASTM American Society for Testing and Materials (2002), Standard Specification for Biodiesel Fuel (B100) Blend. Stock for distillate fuels, designation D6751-02, ASTM Inter.

[20] Yamane K., Ueta A., Shimamoto Y., "Influence of Physical and Chemical Properties of Biodiesel Fuel on Injection, Combustion and Exhaust Emission Characteristics in a DICI Engine" Tran. Of the Japan Society of Mechanical Engineers, Vol. 32, NO: 2, 2001, pp.25-30.

[21] Aworanti OA, Agarry SE, Ajani AO. A laboratory study of the effect of temperature on densities and viscosities of binary and ternary blends of soybean oil, soy biodiesel and petroleum diesel oil", Adv Chem Eng Sci 2012; 2:444-52. 
[22] Nita I, Geacai S., "Study of density and viscosity variation with temperature for fuels used for diesel engine", Ovidius Univ Ann Chem 2011; 22(1): 57-61.

[23] Song C, Hsu CS, Mochida I (2000), "Introduction to chemistry of diesel fuels", New York, Taylor \& Francis, London.

[24] Yamane K., Ueta A., Shimamoto Y.," Influence of Physical and Chemical Properties of Biodiesel Fuel on Injection, Combustion and Exhaust Emission Characteristics in a DICI Engine", Tran. Of the Japan Society of Mechanical Engineers, Vol. 32, No.2, 2001, pp.25-30.

[25] Edward F. Obert, "Internal combustion engines and air pollution", Harper International edition (3/e). Harper \& Row Publishers, Inc. 1973, Page no: 451-453

[26] R.A. Bakar and T.Firoz," Numerical analysis of pressure pulses in the jerk fuel injection systems", American Journal of Applied Sciences 2(5), 2005, pp.1003-1007.

[27] Giffen, E. and A.W. Rowe, "Pressure calculations for oil engine fuel injection system", Proceedings of the Institution of Mechanical Engineers", 142:519-534.,1939.

[28] P V Rao," Pressure-Time Analysis of a Unit Injector", A Thesis submitted to the Indian Institute of Science", Bangalore, India, for the degree of Master of Engineering in Mechanical Engineering. 1993.

[29] Kegl B, Hribernik A (2006)," Experimental Analysis of Injection Characteristics Using Biodiesel Fuel", Energy Fuels, 20:2239-48

[30] Tat ME, Van Gerpen JH, Wang PS (2007)," Fuel property effects on injection timing, ignition timing, and oxides of nitrogen emissions from biodiesel-fueled engines", Transactions of the American Society of Agricultural and Biological Engineers, 50(4): $1123-8$

[31] Flavio Caresana (2011)," Impact of biodiesel bulk modulus on injection pressure and injection timing and the effect of residual pressure", Fuel 90:477-485.

[32] John, A., Elkin, G., Pedro, B., "Experimental combustion analysis of a HSDI diesel engine fueled with palm oil biodiesel -diesel blends", Dyna, Vol. 76, No. 159, 2009, pp.103-113.

[33] Szybist, J. P., Song, J., Alan, M. and Boehman, A. L.," Biodiesel combustion, emissions and emission control", Fuel Processing Technology 88, 679-691, 2007.

[34] Senatore, A., Cardone, M., Rocco, V., Prati, M. V. ," A Comparative analysis of combustion process in D. I. diesel engine fueled with biodiesel and diesel fuel", SAE, 2000-01-0691, 2000.

[35] Aparicio, C., Guignon, B., Rodriguez-Anton, L. M. and Sanz, P. D., "Volumetric properties of sunflower methyl ester oil at high pressure", Journal of agricultural and food chemistry 55, 7394-7398, 2007.

[36] Aparicio, C., Guignon, B., Rodriguez-Anton, L. M. and Sanz, P. D.," Determination of rapeseed methyl ester oil volumetric properties in high pressure $(0.1$ to $350 \mathrm{MPa})$ ", Journal of agricultural and food chemistry Vol. 89, 1, 13-19, 2007.

[37] Suryanarayanan S, Janakiraman VM, Rao GLN, Sampath S., "Comparative study of the performance and emission characteristics of biodiesels from different vegetable oils with diesel", SAE Paper No. 2008-01-1581:2008.

[38] Abhishek Sharma, S. Murugan,"Investigation on the behavior of a DI diesel engine fueled with jatropha Methyl Ester (JME) and tyre Pyrolysis oil (TPO blends)", Fuel 108 (2013) 699-708.

[39] K.F. Hansen, M.G. Jensen, "Chemical and biological characteristics of exhaust emissions from a D I diesel engine fuelled with rapeseed oil methyl ester (RME)", SAE paper, 1997, 971689.

[40] A.C. Pinto, L.L.N. Guarieiro, J.C. Rezende, N.M. Ribeiro, E.A. Torres, E.A. Lopes, et al, "Biodiesel: an overview", Journal of the Brazilian Chemical Society 16 (6B) (2005) 1313-1330. 
[41] X. Shi, Y. Yu, H. He, S. Shuai, J. Wang, R. Li, "Emission characteristics using methyl soyate-ethanol-diesel fuel blends on a diesel engine", Fuel 84 (2005) 1543-1549.

[42] A. Serdari, K. Fragioudakis, C. Teas, F. Zannikos, S. Stournas, E. Lois, "Effect of biodiesel addition to diesel fuel on engine performance and emissions", Journal of Propulsion and Power 15 (2) (1999) 224-231.

[43] Chauhan BS, Kumar N, Cho HM., " A study on the performance and emission of a diesel engine fueled with jatropha biodiesel oil and its blends", Energy, 2012, 37:61622.

[44] M. EL-Kasaby, M.A. Nemit-allah, "Experimental investigations of ignition delay period and performance of a diesel engine operated with Jatropha oil biodiesel", Alexandria Engineering Journal (2013) 52, 141-149.

[45] B. S. Chauhan, N. Kumar, H. M. Cho, "A study on the performance and emission of a diesel engine fueled with Jatropha biodiesel oil and its blends", Energy 37 (2012) $616 \mathrm{e} 622$.

[46] P. V., Rao," Experimental investigations on the Influence of properties of Jatropha biodiesel on performance, combustion, and emission characteristics of a DI-CI engine", World Academy of Science, Engineering and Technology, 75, 2011

[47] V. R. Mamilla, M.V.Mallikarjun, G.L. Rao, "Effect of Combustion Chamber Design on a DI diesel engine fuelled with Jatropha Methyl Esters Blends with diesel" Procedia Engineering 64 ( 2013 ) 479 - 490.

[48] Bhupendra Singh Chauhan, Naveen Kumar, Haeng Muk Cho, "A study on the performance and emission of a diesel engine fueled with Jatropha biodiesel oil and its blends" Energy 37 (2012) 616- 622.

[49] Gaurav P., Ambarish D., Bijan K. M.," An Experimental and numerical investigation of the performance, combustion and emission characteristics of a diesel engine fueled with Jatropha", Biodiesel 4th International Conference on Advances in Energy Research 2013, ICAER 2013.

[50] M. Mofijur, H. H. Masjuki, M. A. Kalam, A. E. Atabani, "Evaluation of biodiesel blending, engine performance and emission characteristics of jatropha curcas methyl ester: Malaysian perspective", Energy (2013) 1-9.

[51] Mohamed said shehata,"Emission, performance and cylinder pressure of diesel engine fuelled by biodiesel fuel", Fuel 112(2013) 513-522.

[52] D.C. Rakopoulos," Heat release analysis of combustion in heavy-duty turbocharged diesel engine operating on blends of diesel fuel with cottonseed or sunflower oils and their bio-diesel", Fuel 96(2012) 524-534.

[53] H. Sharon, Karuppasamy, D.R. Soban Kumar, A. Sundaresan," A test on DI diesel engine fueled with methyl esters of used palm oil", Renewable Energy 47(2012)160166.

[54] M. Satyanarayana, C. Muraleedharan, "A comparative study of vegetable oil methyl esters (biodiesels)", Energy 36 (2011) 2129-2137.

[55] Murugan S, Ramaswamy MC, Nagarajan G.,"Performance, emission and combustion studies of a DI diesel engine using distilled tyre pyrolysis oil- diesel blends", Fuel Process Technol 2008;89: 152-9.

[56] Abhishek Sharma, S. Murugan, "Investigation on the behaviour of a DI diesel engine fueled with Jatropha Methyl Ester (JME) and Tyre Pyrolysis Oil (TPO) blends", Fuel 108 (2013), 699-708. 